Article

\title{
Long-Term Power Outage and Preparedness of the Population of a Region in the Czech Republic-A Case Study
}

\author{
Štěpán Kavan ${ }^{1, *(1)}$, Olga Dvořáčková ${ }^{1} \mathbb{C}$, Jiří Pokorný ${ }^{2} \mathbb{D}$ and Lenka Brumarová ${ }^{2}$ \\ 1 Faculty of Health and Social Studies, University of South Bohemia in Ceske Budejovice, \\ 37011 Ceske Budejovice, Czech Republic; jedla@zsf.jcu.cz \\ 2 Faculty of Safety Engineering, VSB-Technical University of Ostrava, 70030 Ostrava, Czech Republic; \\ jiri.pokorny@vsb.cz (J.P.); lenka.brumarova@vsb.cz (L.B.) \\ * Correspondence: stepan.kavan@email.cz; Tel.: +420-724-178-999
}

check for updates

Citation: Kavan, Š.; Dvořáčková, O.; Pokorný, J.; Brumarová, L. Long-Term Power Outage and Preparedness of the Population of a Region in the Czech Republic-A Case Study. Sustainability 2021, 13, 13142. https:// doi.org/10.3390/su132313142

Academic Editor: Gianpiero Greco

Received: 10 November 2021

Accepted: 26 November 2021

Published: 27 November 2021

Publisher's Note: MDPI stays neutral with regard to jurisdictional claims in published maps and institutional affiliations.

Copyright: (c) 2021 by the authors. Licensee MDPI, Basel, Switzerland. This article is an open access article distributed under the terms and conditions of the Creative Commons Attribution (CC BY) license (https:// creativecommons.org/licenses/by/ $4.0 /)$.

\begin{abstract}
The power outages that have occurred in recent years around the world point to widespread problems with consequences for the lives and health of the population, but also material damage. This is a case study that focuses on the evaluation of the preparedness of the population of a selected region in the Czech Republic for a long-term power outage. This article deals with a case study that focuses on the evaluation of the preparedness of the population of the Karlovy Vary region in the field of emergency survival. Part of the study is the evaluation of the respondents' answers, which provides an overview of the actual state of preparedness for power outages on a sample group of respondents in the Karlovy Vary region. The research method used was a survey using questionnaires. The obtained information was subsequently statistically evaluated by nonparametric correlation

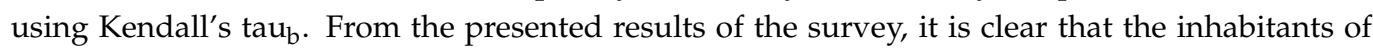
smaller municipalities are better prepared for a power outage and can create basic conditions for emergency survival.
\end{abstract}

Keywords: long-term power outage; security; emergency survival; civil protection; population readiness

\section{Introduction}

We are exposed to many security risks in our daily lives. Some of them are visible at first glance, but there are also those that are hidden and can significantly compromise security. Extensive outages of energy sources, especially oil and electricity, are also a significant risk. Large-scale power outages can significantly affect the society and economy of any state and have an impact on life. Electricity is currently one of the most important types of energy. It can be relatively easily converted into kinetic, thermal, light energy and transmitted over long distances. Modern human society is dependent on electricity supplies. A long-term outage can be a major danger to modern civilization.

The electricity system is a nationwide area system with a high degree of connection to the electricity systems of neighboring countries. It is very sensitive to the proper functions and required interactions of its individual elements. These elements are closely related and they also interact with each other. (I) If the cause of the supply disruption were only a local failure (loss of a few elements or substations), the outage would be short-term and the restoration of power to end customers would be possible in minutes to hours. (II) If there is a system-wide disproportion between electricity production and consumption or a supply outage caused by an overload, frequency, or voltage collapse, the outage can be considered medium-term with a system recovery time of several hours to tens of hours. (III) If an outage is caused by extreme natural causes or a huge terrorist attack that would damage a large part of the critical infrastructure, the resumption of energy supply could take several days or even weeks. 
Long-term power outages are the object of many studies in the field of electricity. From the point of view of security studies and social sciences, this is a relatively new phenomenon. The danger of large-scale power outages was examined mainly from a technical point of view when suitable technical and engineering solutions on how to prevent this phenomenon were sought. The focus was also on how to minimize the consequences of a possible large-scale outage to cause as little damage as possible. Despite all efforts to design safer systems, we are still witnessing major large-scale accidents [1-3]. The socio-technical risk management system is addressed, which includes several levels from legislators, managers, work planners, and system operators [4]. But how is society at the population level prepared for a long-term power outage?

This text deals with the issue of preparedness of the population in the case of a major power outage, which can have serious negative consequences. The goal of the paper is to examine the readiness of the population regarding emergency survival in the event of a long-term power outage in the Karlovy Vary region in the Czech Republic. The study contains its own limitations and does not address the technical aspects of disruption or ensuring the safety and reliability of the electricity system and the regulation of electricity consumption. It also does not examine possible economic impacts. The study does not focus on the evaluation of technical and manipulation readiness of the transmission system for possible long-term power outages, backup by alternative sources, or solutions for priority supply of strategically important entities such as critical infrastructure elements.

According to the authors' survey, the evaluation of the population's readiness for a long-term power outage has not been published in the international environment. Available literature sources mainly focus on the stability of electricity supply, load in the distribution network, and manipulation in the transmission system [5-10]. Other authors focus more on possible causes, disaster prevention, health issues [11-15], resilience, optimization, and risk management in society - with regard to possible social and economic impacts [16-20]. Another view of the issue is the education and training of the population and selected civic associations [21,22]. Other authors address the topic in terms of vulnerability analysis, cultural aspects and warnings [23-25], damage modeling for strengthening the resilience of energy distribution systems, and planning [2,26-28]. However, research results of the level of population readiness for the consequences of a long-term power outage have not been published in the available literature.

The power outages that have occurred in recent years around the world [29] point to widespread consequences for the lives and health of the population, but also to material damage to properties. An overview of selected power outages is shown in Table 1.

Table 1. Selected examples of power outages in the world.

\begin{tabular}{|c|c|c|c|}
\hline Date of Power Outage & Country & Cause & $\begin{array}{l}\text { Population without } \\
\text { Electricity (in Millions) }\end{array}$ \\
\hline 31 March 2015 & Turkey & $\begin{array}{l}\text { Decommission of two power plants and simultaneous } \\
\text { maintenance on transmission lines (not confirmed) }\end{array}$ & 70 \\
\hline 26 October 2012 & Brazil & Fire in the substation & 53 \\
\hline 30-31 July 2012 & India & $\begin{array}{l}\text { Deficit between production and dynamically increasing } \\
\text { consumption (line overload), which was exacerbated by } \\
\text { unfavourable climatic conditions }\end{array}$ & 670 \\
\hline 8 September 2011 & USA a Mexico & $\begin{array}{c}\text { Operator error and subsequent failure of very high } \\
\text { voltage lines }\end{array}$ & 3 \\
\hline 11 March 2011 & Japan & $\begin{array}{l}\text { Decommission of nuclear power plants, after being } \\
\text { damaged by a tsunami caused by an earthquake }\end{array}$ & 4.4 \\
\hline 28 January 2008 & China & A snowstorm destroyed a very high voltage line & 30 \\
\hline 11 November 2009 & Brazil, Paraguay, and Uruguay & Short circuit of 3 transformers due to heavy rains & 60 \\
\hline 18 August 2005 & Indonesia (islands Java and Bali) & $\begin{array}{l}\text { Multiple failures of the power system which knocked out } \\
\qquad 2700 \mathrm{MW} \text { of power }\end{array}$ & 100 \\
\hline 27-28 September 2003 & Italy (except Sardinia) & Storm & 56 \\
\hline 14 August 2003 & USA and Canada & $\begin{array}{l}\text { A short circuit caused by tree branches and consequent } \\
\text { wrong fix of initiation faults }\end{array}$ & 50 \\
\hline 20 February-27 March 1998 & New Zealand & Repeated faults on high voltage cables & $\mathrm{n} / \mathrm{a}$ \\
\hline
\end{tabular}


Population readiness to deal with emergencies and crises, and thus a long-term power outage, is a matter of civil protection by issuing emergency survival measures [30,31]. Civil protection in the Czech Republic is characterized as a set of activities and procedures of competent authorities and other interested bodies, organizations, units, and the population. It aims at minimizing the negative impacts of possible emergencies and crisis situations on human health and lives and living conditions. Emergency survival can be characterized as a temporary way of population survival that has been affected by the consequences of emergencies or crisis situations. It includes measures for emergency accommodation, food, drinking water and energy supply, and the organization of humanitarian aid [32].

The study focuses on the evaluation of the obtained results of a survey aimed at determining the readiness of the population in the field of emergency survival in a situation of a long-term power outage. The article evaluates the answers of the respondents and thus provides an overview of the actual current state of preparedness on a sample group of respondents in the Karlovy Vary region. The hypothesis is formulated as a process of creating orderly knowledge that is based on systematic research. Specifically, the following hypothesis was formulated: H1 Residents of smaller municipalities are better prepared to cope with the consequences of a long-term power outage than residents of urban areas.

The text of the article is structured into individual chapters. The introduction presents the issue of power outages, the aim of the work and the hypothesis. The chapter "Material and methods" focuses on the introduction of research methodology and specification of the topic in relation to crisis management. The next chapter focuses on the presentation of the obtained results. The chapter "Discussion and conclusions" reflects the results of the survey.

\section{Materials and Methods}

To achieve the goal, the authors prepared a research project in the preparatory phase, which was based on empirical preliminary research. Preliminary research is based on a set of classified knowledge on population preparedness for long-term power outages. It also serves as a process of generating knowledge according to certain methodological rules $[33,34]$. The research project is based on the preparatory part-pre-research. This is a survey on a small sample of respondents to verify that the questionnaire is understandable. Subsequently, the comments were incorporated so that the interview could be conducted in full comprehensibility. We used the applied research method, where issues of practical importance were addressed and specific problems in the field of population preparedness were examined. The performed quantitative research was focused on a certain element in natural conditions, which was population readiness for the possible effects of a long-term power outage, and on trying to understand it and create a comprehensive picture of it if possible.

\subsection{Methods}

The main method of the research was a survey in the form of a questionnaire, which was used to obtain information from the inhabitants of the Karlovy Vary region. The questionnaire can be considered as one of the most widespread research techniques. The advantage of the questionnaire is easy and fast administration and the possibility of personal anonymity. The disadvantage can be seen in the formulation of questions, which may not be suitable for everyone. Another disadvantage is a certain subjectivity of the statements. The questionnaire was used to determine the readiness and awareness of individual respondents.

The study was conducted in accordance with the ethical approach of conducting a survey. The research was based on informed consent. Respondents participated in the study only if they agreed. They were fully informed in advance about the course and circumstances of the research. Respondents were aware of their freedom to withdraw from the research without consequences. The protection of the participants' interests ensured 
future anonymity and confidentiality-the protection of identity. The authors informed the respondents about the objectives of the survey.

This empirical research is based on a systematic examination of social phenomena in order to obtain knowledge that describes and explains the population preparedness regarding emergency survival during long-term power outages in the Karlovy Vary region in the Czech Republic. The research was carried out and is described so as to ensure repeatable and verifiable investigations. Two basic steps were taken in the research process:

- exploration; data collection was performed to determine the nature of selected phenomena and relationships in terms of population preparedness for the consequences of long-term power outages; it is an inductive process;

- demonstration; to demonstrate or support the validity of some hypotheses on the basis of the obtained data.

A standardized questionnaire with a fixed structure was used to examine population readiness for a long-term power outage. The questionnaire had a specific set of written questions. They were closed questions, i.e., yes or no questions, dichotomous questions (several possibilities), or one question with one or more answers (disjunctive and conjunctive, or enumerated with order). In open questions, they had the possibility of supplementing their own written answers. The selection of respondents was performed as:

- intentional-the sample group responded with the research goal;

- based on the willingness to participate in the research.

The respondents were addressed by the Fire and Rescue Service of the Karlovy Vary region in cooperation with the Karlovy Vary region in November 2018. The goal was to obtain information on ensuring the basic needs of the population in the event of a long-term power outage. The actual set of questions of the questionnaire was accessible via a web link where the questionnaire was published. The conditions for completing the questionnaire were being over 18 years old and long-term residence in the Karlovy Vary region. The link to the website with the questionnaire was disseminated using official press releases and links on social networks. Residents of the Karlovy Vary region were asked to fill in the questionnaire so that the crisis management authorities could obtain an overview of the basic possibilities, supplies, and needs in the event of a long-term power outage. The survey was closed after two months in January 2019. The survey included 1855 respondents (out of a total of 236,241 long-term residents in the Karlovy Vary region; 0.8\%).

The survey was conducted in the Karlovy Vary region, which is located in the west of the Czech Republic. There are a total of 134 municipalities, which are further divided into 527 parts. Its area of $3310 \mathrm{~km}^{2}$ makes the Karlovy Vary region one of the smallest in the country. It occupies only $4.2 \%$ of the total area of the Czech Republic. As of 31 December 2018 , a total of 236,241 inhabitants lived in the municipalities of the Karlovy Vary region, which represents $2.8 \%$ of the population of the Czech Republic. The Karlovy Vary region is famous mainly for its spas. The most famous spas in the Czech Republic are Karlovy Vary, Mariánské Lázně, Františkovy Lázně, Kynžvart, and Jáchymov.

The survey stated that the study works with a two or more-day power outage. In the event of a major accident, the real possibilities of the system operators may not be able to ensure immediate operation resumption. They also may require the system to be shut down, which would cause a crisis situation in the supply of electricity to customers. Such an emergency can create an increased risk of secondary crises and pose a significant threat to lives, health, property, and the environment. An authorized body may declare one of the crisis situations and state administration bodies may implement crisis measures with the help of the integrated rescue system.

We used statistics to evaluate the obtained information. This can be characterized as a discipline that obtains information from numerical data. It helps in the preparation and implementation of research and in the evaluation of the results obtained. Statistics provide the means to work with the results to understand a particular problem. The statistical procedure was implemented in three basic parts [35]: 
- data acquisition using a questionnaire;

- data analysis, organization of information and numerical summaries and other mathematical resources;

- $\quad$ statistical evaluation/interference, information summary, acquisition and interpretation of phenomena, conclusions about the obtained results.

The method of a statistical survey as a form of quantitative research focuses on and assesses statistical variability and interdependences of variables. The statistical survey was used to obtain structured data, which are then interpreted using the deductive approach. The chosen form of survey was used to assess the information from a selected sample group of the population in the Czech Republic. The monitoring unit (respondent) was one representative of a household. Due to the nature of the research, a descriptive survey was used, which focuses on (and is thus limited) the statistical description of data obtained by assessing the respondents' answers. The procedure can be described as a cross-sectional survey because the collection of data was carried out in one specific time interval. Respondents were asked about the data that were related to the present or recent past, such as alternative sources or supplies of water, food, or medicine.

The use of a structured questionnaire enabled the authors of the study to maintain a fixed order and form of answers for effective statistical processing. The disadvantage of a firmly structured questionnaire is the comprehensibility of the questions, which may limit the reliability. Based on this fact, a preliminary survey was prepared first. In this phase, the pilot questionnaire was filled in by 50 respondents (who provided feedback and evaluation of the wording of the questions). Subsequently, the questions were modified in order to achieve a correct understanding of the questions.

The statistical survey was performed in IBM SPSS 24.0 program (Statistics is the world's leading statistical software used to solve business and research problems by means of ad-hoc analysis, hypothesis testing, and predictive analytics.) using Kendall's rank correlation coefficient tau $u_{b}$ (Kendall's coefficient of concordance), which is a nonparametric variant of Pearson's correlation coefficient. The Kendall's test makes no assumptions about the nature of variables' distribution. A $p$-value of $<0.05$ was considered statistically significant.

\subsection{Long-Term Power Outage and Crisis Management}

The electricity system is a nationwide area system with a high degree of connection to the electricity systems of neighboring states. It is very sensitive to the proper function and required interaction of its individual elements, which are closely related and interact with each other. As electricity cannot be stored in significant quantities, the balance between production and consumption must be maintained at all times. The electricity system must continuously ensure a balance with the changing magnitude of consumption and production of electricity. This balance is ensured by the electricity market and transmission system operators. There are events that, depending on their severity, the extent of the affected area and the frequency of occurrence, can cause damage or loss of function of one or more elements and lead to accidents of a regional or national nature, which in extreme cases can affect the system of continuous interconnection.

If the cause of the outage is only a local failure (loss of a few elements or substations), it would be a short-term outage and the restoration of power would be possible in minutes to hours. In this case, it would most likely be a local outage in a part of a city or territory, and, in most cases, it would not be necessary to take crisis measures according to the Crisis Management Act [36]. The system-wide disproportion between electricity production and consumption, or a supply outage caused by overload, frequency, or voltage collapse, can, in most cases, be considered a medium-term outage with a system recovery time of hours to tens of hours. On the contrary, decommissioning, i.e., damage to a large part of critical infrastructure by extreme natural events or as a result of a huge terrorist attack could mean a resumption of supply lasting several days to weeks (until a replacement solution is implemented, which may include the construction of a replacement line at the site of damage or transport and installation of reserve transformers in affected substations). 
The speed of the resumption of electricity supplies also depends on the cause. If there is extensive physical damage to the infrastructure, the recovery time will be proportional to the extent of the damage (days to weeks in the event of war or planetary disasters). If the entire transmission system, part of it, or a significant area of the electricity system finds itself without voltage, a so-called blackout occurs, which means a large-scale disruption of electricity supply for a large number of customers. European legislation defines a blackout as follows [37]:

The transmission system is in a blackout state if at least one of the following criteria is met:

- more than $50 \%$ of customers were lost in the regulatory area of the given transmission system operator;

- there is a complete lack of voltage in the regulatory area of the transmission system operator for at least three minutes, which leads to the start of the recovery plan.

The cause can be a significant outage of transmission and production equipment, which leads to a subsequent frequency collapse. If such a situation arose, it would be necessary to declare a state of crisis and implement crisis measures and state of emergency in the electricity sector according to the Energy Act [38] on business conditions and the performance of state administration in energy sectors and amendments of certain laws.

In the Czech Republic, it is possible to declare one of four critical situations to deal with large-scale emergencies - a state of danger, a state of emergency, a state of threat to the state, and a state of war [39,40]. Since 2001, when the new crisis legislation came into force in the Czech Republic, a state of danger has been declared in 13 cases and a state of emergency in 6 cases. The state of threat to the state and the state of war have not been declared during this period. An overview of declared crisis situations and the reason for the declaration is given in Table 2. It can be assumed that in the event of a long-term power outage, one of the critical situations would be declared, and it would probably be an emergency situation.

Table 2. Overview of declared critical situations in the Czech Republic [41].

\begin{tabular}{lll}
\hline Year & Critical Situation & Reason for Declaring \\
\hline 2002 & Danger & Flood \\
2002 & Emergency & Flood \\
2004 & Danger & Landslide \\
2004 & Danger & Elimination of the consequences of a natural disaster \\
2005 & Danger & Waterworks failure \\
2006 & Danger & Flood \\
2006 & Emergency & Flood \\
2006 & Danger & Landslide \\
2006 & Danger & Dangerous substances \\
2007 & Emergency & Hurricane Kyrill \\
2009 & Danger & Flood \\
2010 & Danger & Flood \\
2013 & Danger & Flood \\
2013 & Emergency & Flood \\
2014 & Danger & Landslip \\
2016 & Danger & Illegal storage of dangerous substances \\
2017 & Danger & African pig plague \\
2020 & Emergency & Coronavirus SARS-CoV-2 (March, April) \\
$2020 / 2021$ & Emergency & Coronavirus SARS-CoV-2 (October 2020-February 2021) \\
\hline
\end{tabular}

\section{Results}

The anticipated secondary events that may occur as a result of a long-term power outage and events that may occur independently or cumulatively and affect the solution of the situation can include (authors' own reflection):

- disruption of the supply of crude oil and petroleum products; 
- disruption of large-scale gas supplies;

- disruption of large-scale food supplies;

- disruption of large-scale drinking water supplies;

- disruption of the functionality of important electronic communications systems;

- large-scale breaches of legality;

- disruption of heat supplies;

- traffic disruptions (traffic signals, rail transport, airport operations);

- unavailability of information and communication systems.

These secondary events would have an impact on population survival. Therefore, the population was surveyed for readiness, material self-sufficiency, and knowledge of possible procedures in the event of a long-term power outage.

Impacts on the population are the objective of this research and the survey. Each respondent represented one household. Their answers are shown in Table 3. It is obvious that the individual surveyed categories are represented relatively equally. The lowest frequency ( $5 \%$ or less) was recorded for "one-person household", "medicine supply for less than a week", and "ownership of an electrical medical device". Due to the large sample size, only the least represented issue of medical devices was not included in further analyses.

Table 3. Answer percentage in the survey $(n=1855)$.

\begin{tabular}{|c|c|c|c|}
\hline Question & Answers & Frequency & Percentage \\
\hline \multirow{3}{*}{ Size of municipality } & up to 1000 people & 445 & $24.0 \%$ \\
\hline & from 1001 to 10,000 people & 631 & $34.0 \%$ \\
\hline & over 10,000 people & 779 & $42.0 \%$ \\
\hline \multirow{3}{*}{ Housing } & family house & 770 & $41.5 \%$ \\
\hline & residential building & 433 & $23.3 \%$ \\
\hline & prefabricated apartment building & 652 & $35.1 \%$ \\
\hline \multirow{4}{*}{ Number of household members } & 1 & 122 & $6.6 \%$ \\
\hline & 2 & 503 & $27.1 \%$ \\
\hline & 3 & 529 & $28.5 \%$ \\
\hline & 4 and more & 701 & $37.8 \%$ \\
\hline \multirow{2}{*}{ Heating independent of electricity } & no & 1143 & $61.6 \%$ \\
\hline & yes & 712 & $38.4 \%$ \\
\hline \multirow{4}{*}{ Water supply/own well } & $\mathrm{n} / \mathrm{a}$ & 978 & $52.7 \%$ \\
\hline & $1-2$ days & 553 & $29.8 \%$ \\
\hline & $3-5$ days & 191 & $10.3 \%$ \\
\hline & more than 5 days & 133 & $7.2 \%$ \\
\hline \multirow{4}{*}{ Food supply } & $\mathrm{n} / \mathrm{a}$ & 309 & $16.7 \%$ \\
\hline & 1-2 days & 874 & $47.1 \%$ \\
\hline & $3-5$ days & 461 & $24.9 \%$ \\
\hline & more than days 5 & 211 & $11.4 \%$ \\
\hline \multirow{4}{*}{ Medicine supply } & less than 1 week & 70 & $3.8 \%$ \\
\hline & 1 week & 146 & $7.9 \%$ \\
\hline & more than 1 week & 644 & $34.7 \%$ \\
\hline & I do not use & 995 & $53.6 \%$ \\
\hline \multirow{2}{*}{ Cash } & no & 567 & $30.6 \%$ \\
\hline & yes & 1288 & $69.4 \%$ \\
\hline \multirow{2}{*}{ Battery-operated radio/car radio } & no & 543 & $29.3 \%$ \\
\hline & yes & 1312 & $70.7 \%$ \\
\hline \multirow{2}{*}{ Backup power supply } & no & 1679 & $90.5 \%$ \\
\hline & yes & 176 & $9.5 \%$ \\
\hline \multirow{2}{*}{ Cottage without electricity } & no & 1051 & $56.7 \%$ \\
\hline & yes & 804 & $43.3 \%$ \\
\hline \multirow{2}{*}{ Medical electrical appliances } & no & 1841 & $99.2 \%$ \\
\hline & yes & 14 & $0.8 \%$ \\
\hline
\end{tabular}


Due to the ordinal nature of the data and the limited range of used scales, the Kendall's nonparametric correlation coefficient $\operatorname{tau}_{\mathrm{b}}$ was used to evaluate the relationships. The results are shown in Tables 4 and 5. In Tables 4 and 5, the variables are sorted according to the decreasing relation to the size of residence. Correlation coefficients are stated above the diagonal. Below the diagonal, the $p$-values are presented. Statistically significant results are shown in bold.

Table 4. Evaluation of nonparametric correlation of selected characteristics (I) using the Kendall's $\operatorname{tau}_{\mathrm{b}}(n=1855)$.

\begin{tabular}{cccc}
\hline & Size of Municipality & Housing & $\begin{array}{c}\text { Number of } \\
\text { Household } \\
\text { Members }\end{array}$ \\
\hline Size of municipality & & 0.370 & -0.176 \\
\hline Housing & $<0.001$ & & -0.231 \\
\hline Number of household members & $<0.001$ & $<0.001$ & \\
\hline
\end{tabular}

Table 5. Evaluation of nonparametric correlation of selected characteristics (II) using the $\operatorname{Kendall's~tau~}_{\mathrm{b}}(n=1855)$.

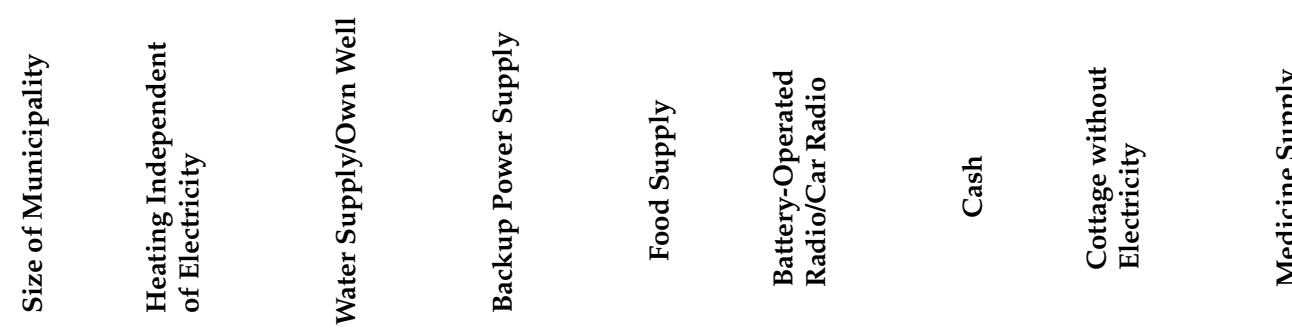

\begin{tabular}{lccccccccc}
\hline Size of municipality & & -0.281 & -0.182 & -0.099 & -0.071 & -0.069 & -0.066 & -0.009 & 0.007 \\
\hline $\begin{array}{l}\text { Heating independent } \\
\text { of electricity }\end{array}$ & $<0.001$ & & 0.153 & 0.142 & 0.116 & 0.198 & 0.083 & 0.039 & 0.009 \\
\hline Water supply/own well & $<0.001$ & $<0.001$ & & 0.186 & 0.313 & 0.150 & 0.171 & 0.102 & 0.056 \\
\hline Backup power supply & $<0.001$ & $<0.001$ & $<0.001$ & & 0.116 & 0.119 & 0.091 & 0.066 & 0.041 \\
\hline Food supply & $<0.001$ & $<0.001$ & $<0.001$ & $<0.001$ & & 0.121 & 0.148 & 0.076 & 0.145 \\
\hline $\begin{array}{l}\text { Battery-operated } \\
\text { radio/car radio }\end{array}$ & 0.002 & $<0.001$ & $<0.001$ & $<0.001$ & $<0.001$ & & 0.152 & 0.116 & 0.042 \\
\hline Cash & 0.003 & $<0.001$ & $<0.001$ & $<0.001$ & $<0.001$ & $<0.001$ & & 0.129 & 0.060 \\
\hline Cottage without electricity & 0.666 & 0.094 & $<0.001$ & 0.005 & $<0.001$ & $<0.001$ & $<0.001$ & & -0.025 \\
\hline Medicine supply * & 0.812 & 0.786 & 0.070 & 0.218 & $<0.001$ & 0.208 & 0.071 & 0.456 & \\
\hline
\end{tabular}

* The number of observations is limited to 860 , the category "I do not use medicaments" is excluded.

The presented results show that the size of the municipality, the type of housing, and the number of people in the household are significantly related $(p<0.001)$. With the increasing size of the residence/municipality, the share of residential and prefabricated apartment buildings increases (Kendall's tau $\mathrm{u}_{\mathrm{b}}=0.370$ ), and the number of people in households decreases $\left(\operatorname{tau}_{b}=-0.176\right)$. The smaller number of people in a common household is also related to the growing proportion of residential and prefabricated apartment buildings $\left(\operatorname{tau}_{\mathrm{b}}=-0.231\right)$.

The presented results clearly show that the dependence of respondents on external electricity supplies $\left(\operatorname{tau}_{\mathrm{b}}=-0.281\right)$, emergency water supply $\left(\operatorname{tau}_{\mathrm{b}}=-0.182\right)$, food availability $\left(\operatorname{tau}_{\mathrm{b}}=-0.071\right)$, etc., grow with the growing size of a municipality. Cottage ownership and the availability of medicaments are not related to the size of the municipality. It is obvious that the individual studied areas are positively correlated, e.g., higher availability of durable food is connected with heating independent of electricity, availability of own drinking water, backup power supply, battery-operated radio/car radio, cash, and cottage 
ownership. In the case of the supply of medicaments, only the relationship to the availability of food was found-greater availability of medicaments is related to higher availability of durable foods and vice versa.

\section{Discussion}

This research was carried out as a systematic study of social phenomena in order to obtain knowledge that describes and explains the current preparedness of the population for the consequences of long-term power outages [42]. The research included a systematic process of collecting information, synthesizing existing knowledge, and achieving an increase in knowledge [43]. The goal was to obtain a unified view of the subject of the study - the readiness of the population of the selected region in the Czech Republic for a long-term power outage. On the one hand, the goal was to isolate individual topics of security issues-civil protection. On the other hand, the individual areas were studied in the context of social areas, i.e., regarding the population.

The presented results of the survey show that residents in smaller municipalities are less dependent on electricity supplies and, in the event of a supply outage, can create basic conditions for emergency survival. On the contrary, the assumption that the inhabitants of larger municipalities and especially cities were dependent on external assistance was confirmed. In the preparation of this study, we reflected the idea that the population of smaller municipalities (especially in the agricultural countryside) had already lost the ability to be partially self-sufficient. However, the results of the study have shown that the inhabitants of smaller municipalities still have the possibility of an emergency supply of drinking water, their own stored food, and can use solid fuel stoves regardless of electricity supply.

The results of the questionnaire survey show that, in terms of basic security of water supplies or own wells, more than half of the respondents (52.7\%) are not secured for possible disruption of water supplies. On the other hand, the results of the survey show information for crisis management authorities. $47.3 \%$ of respondents have at least a minimum supply of drinking water. The majority of respondents $(83.3 \%)$ have food supplies for at least one to two days. The question about the battery-operated radio or car radio aimed at the possibilities of emergency transmission of information after the failure of the backed-up warning network (regular session at a certain time). $70.7 \%$ of the population had this option. Crisis management authorities can build their disaster preparedness and planning documents using this information.

In the event of a long-term interruption of electricity supply, the basic social impacts (A) and the impacts on people's lives and health (B) can be characterized. The preparedness of the population and crisis management bodies must aim at minimizing the negative consequences.

(A) Social impacts (authors' own reflection)

- the risk of very serious social and health impacts on the daily life of the population;

- the risk of a rapid rise in unemployment due to the forced reduction of economic activities, reduction of capacity, and significant economic losses of economic operators;

- the risk of limiting or impossibility of providing basic social services to the population;

- the risk of a significant decline in the living standards of the population as a result of a probable economic shock (property damage, loss of employment, inflation, etc.);

- the risk of serious disturbance of public order and security.

(B) Impacts on people's lives and health (authors' own reflection)

- direct threat to the life and health of the operating personnel of electricity production plants;

- direct danger to the life and health of workers liquidating the consequences of the electricity system damage;

- direct threat to the life and health of the population as a result of a radiation accident, explosion, or fire; 
- endangerment of life and health of the population due to reduction or interruption of electricity supply (medical facilities, social care institutions, heating, etc.);

- endangerment of life and health of the population due to the emergence of secondary crisis situations (e.g., risk of epidemics, disruption of food and drinking water supply, disruption of information and communication systems, disruption of supplies of medicaments and medical supplies, etc.).

If there is a power failure, it is always advisable to turn on the radio (portable, mobile phone, or car radio) to find out more detailed information. Further information can usually be obtained from the municipal office. In crisis situations, there are always people who start spreading unsubstantiated or alarming news. Therefore, it is necessary to obtain information from verified and trusted sources. It is always necessary to follow the instructions of the intervening rescue services, public administration bodies, and energy suppliers.

The effects of a long-term power outage will have an impact on all residents of the affected area [44]. Much more noticeable effects will be felt in areas with a higher concentration of people [45]. The consequences in the life of the population can manifest as follows (authors' own reflection):

- $\quad$ in lifts, unless they are equipped with special backup power supplies;

- in public transport, especially in trains on electrified lines;

- in traffic jams due to a malfunction of traffic signaling devices.

- Other noticeable impacts of this emergency will include:

- limitations in available information;

- overloaded telephone networks; it will be very difficult to establish contact with close persons;

- worse access to the integrated rescue system, overloading of emergency lines, longer travel times of individual means of transport;

- limited operation of hospitals that perform only urgent operations, etc.;

- limited possibilities of ensuring hygienic standards, non-functioning water supplies, and waste, spoiling food, etc.;

- limited possibility to buy food and water;

- limited purchase of fuel;

- limited possibilities in providing heating;

- increased risk of fires, emergency lighting with candles, etc.;

- inability to work and attend school, most buildings and production facilities will be closed;

- limited possibility of transport, limited use of means of public transport, lack of fuel in motor vehicles, etc.

The most important part of the preparations for long-term power outages and other emergencies (e.g., floods) is the creation of sufficient food and water supplies. These supplies should be sufficient for at least 3 days for all members of the household. Bottled water is best suited to create a sufficient supply of drinking water. In general, durable foods that are suitable for quick preparation and can be commonly used at home even in a time of non-crisis are recommended.

A power outage will disable most kitchen stoves. Households that can use solid fuel stoves to heat water and food are at an advantage. A suitable alternative may also be a camping stove-gas, petrol, or alcohol. In such a case, it is important to have a sufficient supply of fuel and matches. An outdoor barbecue can also be used outdoors to prepare meals.

The relationship between the findings and specialized literature is very difficult to characterize. This fact is based on the fact that a similar study has not been presented in the literature. Therefore, the results of the submitted survey cannot be discussed on the basis of other expert sources. 


\section{Conclusions}

Power outage is one of the real technical threats to the functioning of the municipality, the region, and ultimately the entire country $[46,47]$. With the current dependence of modern society on the flawless supply of electricity, disruption of its supply will cripple the functionality of vital everyday equipment. The country's crucial responsibility is to create conditions for reliable and long-term secure energy supplies at affordable prices, and create conditions for its efficient use that will not endanger the environment and will be in accordance with the principles of sustainable development.

The benefit and novelty of this study is the examination of the attitude and readiness of the sample group of respondents in relation to the consequences of a possible catastrophe due to a long-term interruption of electricity supply. Research in this area helps us to understand not only the boundaries that limit our lives but also opens up opportunities to improve human conditions. Knowledge is achieved on the basis of a scientific approach, which is solved as an organized system of acquiring and processing knowledge in the subject area. The goal of this scientific research was to reveal the laws and theory formulation that reveal the real state of the studied society. The information and findings in this study were passed on for further use to the Regional Office of the Karlovy Vary region, which is the crisis management body, and to the Fire and Rescue Service of the Karlovy Vary region, which is the body coordinating activities in civil protection matters.

The research was carried out using questionnaires in order to verify the validity of the theory $[48,49]$. The research enabled the authors to obtain measurable information on the readiness of the population in the event of a long-term power outage, which they subsequently operationalized. The research process fully respected the ethical side of the survey and the interpretation of the results $[50,51]$. The results of the study were presented to the representatives of crisis management authorities, who are responsible for preparing the population for emergencies. The information will be transferred into practice by training, campaigns on social networks, and the Internet.

Based on the results of Kendall's correlation coefficient, we found that residents of smaller municipalities are better prepared to cope with the consequences of a longterm power outage than residents of urban areas. The validity of this hypothesis was confirmed regarding heating, backup sources of electricity, water and food, radios, and cash. Regarding emergency accommodation, the ownership of the cottage is equally probable when the respondents were compared by the size of their residence. The study also found that residents of larger municipalities have a smaller food supply than residents of smaller municipalities.

The benefit of the survey was also its educational character. Thanks to the survey, respondents became aware of the possible extent of the disaster and the areas that may be affected. From the reactions of the respondents, it is clear that they were not aware of many facts, which was reflected in their completed questionnaires. The very implementation of the survey meant a certain level of education and prevention for the population.

The validity of the research is evident from the fulfillment of the requirement of relevance between the research goal, the procedure, and the achieved results - the goal issue was examined $[50,52,53]$. The validity of the objective "to examine the preparedness of the population in the field of emergency survival in the event of a long-term power outage in the Karlovy Vary region" includes two aspects: whether the stated research goal was met and whether a true picture of reality was obtained. The research approach included the requirement of truthfulness, objectivity, and accuracy. We can state that the research procedure fulfilled the research goal, and an overview of the current state of preparedness of the population was obtained.

It would be interesting to conduct a similar study in the Czech Republic in the future to find out how the perception of the population has developed based on the experience of the COVID-19 epidemic and the tornado in 2021. In addition to comparing the results in terms of development over time, it would be interesting to carry out a similar study in other countries and compare the results obtained. 
Author Contributions: Conceptualization, Š.K.; methodology, Š.K., O.D.; software, O.D.; validation, Š.K., O.D., J.P. and L.B.; formal analysis, Š.K.; investigation, Š.K.; resources, Š.K., O.D., J.P. and L.B.; data curation, Š.K.; writing-Š.K., O.D., J.P. and L.B.; writing-review and editing, Š.K.; project administration S.K. All authors have read and agreed to the published version of the manuscript.

Funding: Please carefully check the funding information especially the accuracy of the funding number. Changes will not be possible after proofreading.

Institutional Review Board Statement: The investigations were carried out following the rules of the Declaration of Helsinki of 1975. All subjects gave their informed consent for inclusion before they participated in the study (Long-term power outage and preparedness of the population of a selected region in the Czech Republic - a case study). All participants were fully informed that the anonymity is assured, why the research was being conducted, how their data will be used and there are not any risks associated. The information was processed in such a way as to ensure the anonymity of the respondents. This fully ensures the protection of respondents in accordance with Act No. 101/2000 Coll., On the protection of personal data and on the amendment of certain acts.

Informed Consent Statement: Informed consent was obtained from all subjects involved in the study.

Data Availability Statement: We choose to exclude this statement, the study did not report any data.

Conflicts of Interest: The authors declare no conflict of interest.

\section{References}

1. Lai, C.S.; Locatelli, G. Economic and financial appraisal of novel large-scale energy storage technologies. Energy 2021, 214, 118954. [CrossRef]

2. Shield, S.A.; Quiring, S.M.; Pino, J.V.; Buckstaff, K. Major impacts of weather events on the electrical power delivery system in the United States. Energy 2021, 218, 119434. [CrossRef]

3. Tothova, V.; Bartlova, S.; Sedova, L.; Treslova, M.; Chloubova, I.; Proskova, E. The nurse's role in preventive care in the field of community nursing. Neuroendocrinol. Lett. 2014, 35, 26-33, ISSN 0172-780X.

4. Rasmussen, J. Risk management in a dynamic society: A modelling problem. Saf. Sci. 1997, 27, 183-213. [CrossRef]

5. Tabibzadeh, M.; Lahiry, S. Adopting the AcciMap Methodology to Investigate a Major Power Blackout in the United States: Enhancing Electric Power Operations Safety. In Advances in Intelligent Systems and Computing; Ahram, T., Ed.; Springer: Cham, Switzerland, 2020; Volume 1213, pp. 581-588.

6. MollahassaniPour, M.; Taheri, I.; Marzooni, M.H. Assessment of transmission outage Contingencies' effects on bidding strategies of electricity suppliers. Int. J. Electr. Power Energy Syst. 2020, 120, 106053. [CrossRef]

7. Mishra, D.K.; Ghadi, M.J.; Azizivahed, A.; Li, L.; Zhang, J. A review on resilience studies in active distribution systems. Renew. Sustain. Energy Rev. 2021, 135, 110201. [CrossRef]

8. Salim, N.A.; Jasni, J.; Othman, M.M. Reliability assessment by sensitivity analysis due to electrical power sequential tripping for energy sustainability. Int. J. Electr. Power Energy Syst. 2021, 126, 106582. [CrossRef]

9. Bashkari, M.S.; Sami, A.; Rastegar, M. Outage Cause Detection in Power Distribution Systems Based on Data Mining. IEEE Trans. Ind. Inform. 2021, 17, 640-649. [CrossRef]

10. Ghasemi, S.; Mohammadi, M.; Moshtagh, J. A new Look-ahead Restoration of Critical Loads in the Distribution Networks during Blackout with considering Load curve of Critical Loads. Electr. Power Syst. Res. 2021, 191, 106873. [CrossRef]

11. Tsadikovich, D.; Kamble, A.; Elalouf, A. Controlled information spread for population preparedness in disaster operations management. Int. J. Disaster Risk Reduct. 2020, 42, 101338. [CrossRef]

12. Gaston, S.A.; Galea, S.; Cohen, G.H.; Kwok, R.; Rung, A.L.; Peters, E.S.; Jackson, C.L. Potential Impact of 2020 US Decennial Census Data Collection on Disaster Preparedness and Population Mental Health. Am. J. Public Health 2019, 109, 1079-1083. [CrossRef] [PubMed]

13. Aliyan, E.; Aghamohammadi, M.; Kia, M.; Heidari, A.; Shafie-Khah, M.; Catalão, J.P. Decision tree analysis to identify harmful contingencies and estimate blackout indices for predicting system vulnerability. Electr. Power Syst. Res. 2020, 178, 106036. [CrossRef]

14. Rossnerova, A.; Honkova, K.; Pavlikova, J.; Skalicka, Z.F.; Havrankova, R.; Solansky, I.; Rossner, P.; Sram, R.J.; Zölzer, F. Mapping the factors affecting the frequency and types of micronuclei in an elderly population from Southern Bohemia. Mutat. Res. Mol. Mech. Mutagen. 2016, 793-794, 32-40. [CrossRef] [PubMed]

15. Casey, J.A.; Fukurai, M.; Hernández, D.; Balsari, S.; Kiang, M.V. Power Outages and Community Health: A Narrative Review. Curr. Environ. Health Rep. 2020, 7, 371-383. [CrossRef]

16. Ding, T.; Li, C.; Yan, C.; Li, F.; Bie, Z. A Bilevel Optimization Model for Risk Assessment and Contingency Ranking in Transmission System Reliability Evaluation. IEEE Trans. Power Syst. 2017, 32, 3803-3813. [CrossRef]

17. Tselios, V.; Tompkins, E.L. Can we prevent disasters using socioeconomic and political policy tools? Int. J. Disaster Risk Reduct. 2020, 51, 101764. [CrossRef] 
18. Tselios, V.; Tompkins, E.L. What causes nations to recover from disasters? An inquiry into the role of wealth, income inequality, and social welfare provisioning. Int. J. Disaster Risk Reduct. 2019, 33, 162-180. [CrossRef]

19. Vaillancourt, A.; Haavisto, I. Country logistics performance and disaster impact. Disasters 2015, 40, 262-283. [CrossRef]

20. Oulehlová, A.; Kavan, Š. Preparation for Providing Crisis Communication during Blackout Occurence. In Vision 2020: Sustainable Economic Development, Innovation Management and Global Growth. In Proceedings of the 30th International Business Information Management Association Conference, Madrid, Spain, 8-9 November 2017; pp. 1416-1425.

21. Drotárová, J.; Reitšpís, J. The Identification of Economic and Organization Problems in the Training Process of Municipal Volunteer Fire Department Members in Slovak Republic and its Optimization. Aust. J. Educ. Sci. 2018, 11, 329-346.

22. Mitsova, D.; Esnard, A.-M.; Sapat, A.; Lamadrid, A.; Escaleras, M.; Velarde-Perez, C. Effects of Infrastructure Service Disruptions Following Hurricane Irma: Multilevel Analysis of Postdisaster Recovery Outcomes. Nat. Hazards Rev. 2021, 22, 04020055. [CrossRef]

23. Yang, S.; Chen, W.; Zhang, X.; Yang, W. A Graph-based Method for Vulnerability Analysis of Renewable Energy integrated Power Systems to Cascading Failures. Reliab. Eng. Syst. Saf. 2021, 207, 107354. [CrossRef]

24. Murata, A. Cultural aspects as a root cause of organizational failure in risk and crisis management in the Fukushima Daiichi disaster. Saf. Sci. 2021, 135, 105091. [CrossRef]

25. Centelles, R.P.; Meseguer, R.; Freitag, F.; Navarro, L.; Ochoa, S.F.; Santos, R.M. LoRaMoto: A communication system to provide safety awareness among civilians after an earthquake. Futur. Gener. Comput. Syst. 2021, 115, 150-170. [CrossRef]

26. Hughes, W.; Zhang, W.; Bagtzoglou, A.C.; Wanik, D.; Pensado, O.; Yuan, H.; Zhang, J. Damage modeling framework for resilience hardening strategy for overhead power distribution systems. Reliab. Eng. Syst. Saf. 2021, 207, 107367. [CrossRef]

27. Peng, L.; Hu, B.; Xie, K.; Tai, H.-M.; Yan, J.; Zhou, J. Analytical model of power system hardening planning for long-term risk reduction. Int. J. Electr. Power Energy Syst. 2021, 125, 106449. [CrossRef]

28. Thürmer, J.L.; Wieber, F.; Gollwitzer, P.M. Management in times of crisis: Can collective plans prepare teams to make and implement good decisions? Manag. Decis. 2020, 58, 2155-2176. [CrossRef]

29. Wang, B.; You, D.; Yin, X.; Chen, Q.; Wang, K.; Liu, H.; Hou, H. A method for assessing power system security risk. In Proceedings of the 2010 Asia-Pacific Power and Energy Engineering Conference, Chengdu, China, 28-31 March 2010; pp. 1-5. [CrossRef]

30. Kováčová, L.; Drotárová, J.; Lošonczi, P. Comparison of Preparation Of Selected Target Groups In The Field Of Fire Protection In The Visegrad 4 Countries. Ann. Burns Fire Disasters 2020, 33, 162-169.

31. Palmos, D.; Papavasileiou, C.; Papakitsos, E.C.; Vamvakeros, X.; Mavrakis, A. Enhancing the environmental programmes of secondary education by using web-tools concerning precaution measures in civil protection: The case of Western Attica (Greece) Saf. Sci. 2021, 135, 105117. [CrossRef]

32. Ministry of the Interior of the Czech Republic. Terminological Dictionary of Terms from the Field of Crisis Management, Population Protection, Environmental Security and National Defense Planning; Ministry of the Interior of the Czech Republic: Praha, Czech Republic, 2016. (In Czech)

33. Reichel, J. Kapitoly Metodologie Sociálních Výzkumu; Grada: Praha, Czech Republic, 2009.

34. Greer, A.; Trainor, J.E. A system disconnected: Perspectives on post-disaster housing recovery policy and programs. Nat. Hazards 2021, 106, 303-326. [CrossRef]

35. Hendl, J. Přehled Statistických Metod. Analýza a Metaanalýza Dat; Portál: Praha, Czech Republic, 2009.

36. Act No. 240/2000 Coll., on Crisis Management and on Amendments to Certain Acts (Crisis Act). Collection of Laws $73 / 2000$ of 9 August 2000. Available online: https:/ / ec.europa.eu/echo/sites/default/files/240_2000_crisis_management_act.pdf (accessed on 5 September 2021). (In Czech)

37. Commission Regulation (EU) 2017/1485 of 2 August 2017 Establishing a Guideline on Electricity Transmission System Operation. L 220/1, 25. 8. 2017. Available online: http:/ / data.europa.eu/eli/reg/2017/1485/oj (accessed on 5 September 2021).

38. Act No. 458/2000 Coll., on Business Conditions and the Performance of State Administration in the Energy Sectors and on the Amendment of Certain Acts. Collection of Laws 131/2000 of 29 December 2000. Available online: https: / / www.zakonyprolidi. cz/cs/2000-458 (accessed on 5 September 2021). (In Czech)

39. Dušek, J. International Cooperation of Regional Authorities of the Czech Republic: History, Presence and Future. In Proceedings of the 18th International Colloquium on Regional Sciences, Hustopee, Czech Republic, 17-19 June 2015; Klímová, V., Žítek, V., Eds.; Masarykova Univerzita: Brno, Czech Republic, 2015; pp. 300-305. (In Czech)

40. Maléřová, L. Assessment of Safety Level Risks. In Crisis Management: A Leadership Perspective; VanVactor, J.D., Ed.; Nova Science Publishers Inc.: New York, NY, USA, 2016; pp. 127-139.

41. Kavan, S. Selected social impacts and measures resulting from the Covid-19 epidemic in the Czech Republic on the specific example of the South Bohemian Region. Health Soc. Care Community 2021, 29, 1-8. [CrossRef]

42. Moutinho, L.; Huarng, K. Quantitative Modelling in Marketing and Management; World Scientific: Hackensack, NJ, USA, 2012.

43. Jensen, N.; Rice, A.; Soland, J. The Influence of Rapidly Guessed Item Responses on Teacher Value-Added Estimates: Implications for Policy and Practice. Educ. Eval. Policy Anal. 2018, 40, 267-284. [CrossRef]

44. Pokorny, J.; Tomaskova, M.; Balazikova, M. Study of changes for selected fire parameters at activation of devices for smoke and heat removal and at activation of fixed extinguishing device. MM Sci. J. 2015, 2015, 764-767. [CrossRef] 
45. Morgenstern, J.D.; Rosella, L.C.; Daley, M.J.; Goel, V.; Schünemann, H.J.; Piggott, T. “AI's gonna have an impact on everything in society, so it has to have an impact on public health": A fundamental qualitative descriptive study of the implications of artificial intelligence for public health. BMC Public Health 2021, 21, 40. [CrossRef] [PubMed]

46. Kinzhikeyev, S.; Rohács, J.; Rohács, D.; Boros, A. Sustainable Disaster Response Management Related to Large Technical Systems. Sustainability 2020, 12, 10290. [CrossRef]

47. Hennau, S. The Relationship between Politics and Administration at the Flemish Local Level: Intermunicipal Differences Explained. NISPAcee J. Public Adm. Policy 2020, 13, 141-160. [CrossRef]

48. Skedsmo, G.; Huber, S.G. Reliability, validity and fairness-key issues in assessing the quality of teaching, instructional leadership and school practice. Educ. Assess. Eval. Account. 2018, 30, 343-346. [CrossRef]

49. Johnsson, L. Multidimensional Property Supplementation: A Method for Discovering and Describing Emergent Qualities of Concepts in Grounded Theory Research. Qual. Health Res. 2021, 31, 184-200. [CrossRef]

50. Dania, A.; Griffin, L.L. Using social network theory to explore a participatory action research collaboration through social media. Qual. Res. Sport Exerc. Health 2021, 13, 41-58. [CrossRef]

51. Kavan, Š. Výsluhové nároky příslušníků bezpečnostních sborů v České republice Mezinárodní konference Safe and Secure Society 2020. Sb. Př́sp 2020, 52-60. [CrossRef]

52. Krocova, S. Prottection of aquatic ecosystems against accidents in the Czech Republic. Inž. Miner. 2015, 36, 225-230.

53. Blecharz, P.; Štverková, H. Assessing the Service Quality in Small and Medium-Sized Companies. Actual Probl. Econ. 2014, 154, 206-218. 